\title{
Pensions and aging
}

\section{A selection of papers presented at the $64^{\text {th }}$ Congress of the International Institute of Public Finance, held in Maastricht, the Netherlands}

\author{
Helmuth Cremer • Pierre Pestieau
}

Published online: 30 July 2009

(C) Springer Science+Business Media, LLC 2009

The $64^{\text {th }}$ Congress of the International Institute of Public Finance focused on the theme "pensions and aging." This emphasis is also reflected in the selection presented here. The first two papers of this issue are based on two of the keynote lectures, namely "Pensions and fertility: in search of a link," by Firouz Gahvari, and "Developments in pension reform: the case of Dutch stand-alone collective pension schemes," by Lans Bovenberg. They deal with two key topics. The interaction between unfunded pensions and fertility, which is the subject of Firouz Gahvari's paper, is a major concern in the debate. This is particularly so in many OECD countries, which experience unsustainable pension systems along with fertility rates well below the replacement level. Lans Bovenberg considers the financial viability of pensions systems with the need to find a compromise between defined-benefit and defined-contribution schemes; this is also a hot topic for economists and non-economists alike.

Firouz Gahvari starts by noting that fertility choice has both a positive and a negative externality. He argues that these can be internalized through a child allowance (or tax) or through a linkage between pension benefits and the number of children. In other words, this externality may justify pension benefits (or contributions) that are related to fertility. As he points out, this prescription rests crucially on the assumption that no parents are better than others in raising their children (there is no adverse selection problem) and that fertility can be perfectly controlled (there is no uncertainty and no moral hazard). When either of these two assumptions is violated, the case for such policy recommendations is greatly weakened.

\footnotetext{
H. Cremer $(\bowtie)$

Toulouse School of Economics (IDEI, GREMAQy and Institut universitaire de France), 21 allée de Brienne, 31000 Toulouse, France

e-mail: CremerHelmuth@aol.com

P. Pestieau

Université de Liège and CORE, Liege, Belgium
} 
While the first keynote lecture is about demographics, the second one deals with the financial side of pensions. At the outset, Lans Bovenberg recalls the serious weaknesses in both defined-benefit pensions (credit risk of the sponsor, ambiguous ownership of the surplus, and backloading of benefits) and defined-contribution systems (individuals are not well equipped to make the complex financial decisions involved, transaction costs are substantial, and various risks are not managed properly over the life cycle). He then argues that stand-alone collective pension plans in which members share the risk among themselves offer an attractive third way between these two schemes. The funds manage risk aimed at providing an adequate income level during retirement at low costs. This income level can for instance be defined as a percentage of average past earnings. However, unlike under a defined-benefit system, the specified annuity levels are goals rather than guarantees. The author illustrates potential benefits of stand-alone cooperative pension funds by presenting the system of occupational pension plans in the Netherlands. He argues that Dutch pension funds are evolving in the direction of such stand-alone pension schemes.

Aging is expected to lead to an increasing pressure on health care and long term care schemes. In their paper, "Efficiency potential and determinants of efficiency: an analysis of the care for the elderly sector in Norway," Lars Erik Borge and Marianne Haraldsvik study efficiency in the Norwegian care for the elderly sector. Using the DEA (Data Envelopment Analysis) approach to construct a best practice frontier, they find substantial variations in efficiency across municipalities. The efficiency potential at the national level is estimated at $10 \%$. They use Tobit regressions and bootstrap techniques to explain variations in efficiency. Their results suggest that three factors, namely high fiscal capacity, low degree of user charge financing, and a fragmented local council, appear to be responsible for low efficiency.

One of the main rationales for public pensions is myopia, which calls for forced saving. In their contribution, " Short horizons, time inconsistency, and optimal social security," Scott Findley and Frank Caliendo examine the link between shortsightedness and the value of social security participation, while accounting for generalequilibrium effects (by simulating a calibrated model). Their main findings are that the optimal social security tax rate is always positive across feasible calibrations of their baseline model. Furthermore, they show that individuals with short planning horizons (less than 7 years) benefit from a program such as the US social security at the expense of farsighted individuals.

In their article, "A mean and variance utility approach," Marie-Louise Leroux and Grégory Ponthière study redistribution between agents who can influence their survival probability through private health spending, but who also differ in their attitude toward the risks involved in the lotteries of life to be chosen. The authors adopt a normative perspective. They show that if agents ignore the impact of their health spending on the return of their savings, then a tax on health spending happens to be desirable in the first best. However, in the second best, this is not necessarily the case because a health subsidy (or a lower tax) can relax the incentive problem.

In their paper, "Investing for the old age: pensions, children, and savings," Paola Profeta, Vincenzo Galasso, and Roberto Gatti argue that the interplay of pension generosity and development of capital markets is crucial to understanding fertility decisions. Children have traditionally represented for parents a form of retirement 
saving, particularly in economies with limited or nonexistent capital markets. An exogenous increase of pension spending provides a saving technology alternative to children. Consequently, it relaxes financial (saving) constraints and reduces fertility. The authors build a simple two-period OLG model to show that an increase in pensions is associated with a larger decrease in fertility in countries in which individuals have less access to financial markets. Cross-country regression analysis supports their results: there is interaction between various measures of pension generosity, and a proxy for the development of financial markets consistently enters the regressions positively and significantly. This suggests that in economies with limited financial markets, children represent a possible (if not the only) way for parents to save for old age, and that an increase in pensions effectively relaxes these constraints.

Finally, we have two papers that are not related to pensions. Alexander Kemnitz, in his article, "Native welfare losses from high skilled immigration," explores the effects of high skilled immigration to a host country with unionized low skilled labor and an unemployment insurance scheme. He shows that such immigration can create a negative immigration surplus due to adverse effects on low skilled employment. This result obtains provided that fiscal redistribution is not too intense and that (as empirical evidence suggests) high and low skilled labor are sufficiently close, albeit imperfect, substitutes in the production process.

In their paper, "Neutral taxation of shareholder income? Corporate responses to an announced dividend tax," Annette Alstadsæter and Erik Fjærli deal with the importance of timing in tax reform. They study the introduction of the 2006 Norwegian shareholder income tax that was announced in advance. Their inquiry is based on a large panel of nonlisted corporations. They document strong timing effects on dividend payout, with a surge of dividends prior to 2006 and a sharp drop after. Mature firms are more likely to pay dividends, and high asset growth increases the probability of retaining all earnings. Intertemporal income shifting through the timing of dividends appears to represent a drain on internal equity by increasing the corporations' debt-equity ratios. The debt ratios drop sharply after the implementation of the reform.

Last but not least, we would like to thank Tom van Veen and his team for the outstanding local arrangements. The organization was simply flawless (and by now Tom may actually miss our refreshing emails). We have also benefited tremendously from the prompt and competent responses of the program committee. To prepare this special issue, we had to process a large number of submissions in a very short time. We found many cooperative referees to make this endeavor possible. Our thanks go to all of them. 